\title{
Recent advances in cattle functional genomics and their application to beef quality
}

\author{
J.-F. Hocquette ${ }^{1 \dagger}$, S. Lehnert' ${ }^{2}$, W. Barendse ${ }^{2}$, I. Cassar-Malek ${ }^{1}$ and B. Picard ${ }^{1}$ \\ ${ }^{1}$ INRA, Herbivore Research Unit, Muscle Growth and Metabolism Group, Clermont-Ferrand/Theix Research Centre, Theix, 63122 Saint-Genès Champanelle, France; \\ ${ }^{2}$ CSIRO Livestock Industries and CRC for Beef Genetic Technologies, Australia
}

(Received 10 June 2006; Accepted 25 October 2006)

\begin{abstract}
The advent of high-throughput DNA sequencing techniques, array technology and protein analysis has increased the efficiency of research in bovine muscle physiology, with the ultimate objective of improving beef quality either by breeding or rearing factors. For genetic purposes, polymorphisms in some key genes have been reported for their association with beef quality traits. The sequencing of the bovine genome has dramatically increased the number of available gene polymorphisms. The association of these new polymorphisms with the variability in beef quality (e.g. tenderness, marbling) for different breeds in different rearing systems will be a very important issue. For rearing purposes, global gene expression profiling at the mRNA or protein level has already shown that previously unsuspected genes may be associated either with muscle development or growth, and may lead to the development of new molecular indicators of tenderness or marbling. Some of these genes are specifically regulated by genetic and nutritional factors or differ between different beef cuts. In recognition of the potential economic benefits of genomics, public institutions in association with the beef industry are developing livestock genomics projects around the world. From the scientific, technical and economical points of view, genomics is thus reshaping research on beef quality.
\end{abstract}

Keywords: beef, muscle physiology, genomics, indicators of quality

\section{Introduction}

Beef consumers increasingly seek meat of high and consistent quality. As a consequence, the beef industry is investing in research aimed at the identification of indicators of quality and an increased understanding of muscle biology to control quality traits.

Beef quality includes sensory quality traits (tenderness, flavour, juiciness, colour, etc), nutritional value, healthiness and technological quality (Geay et al., 2001) and also other issues such as animal welfare, environmental concerns, traceability, etc (Hocquette and Gigli, 2005). Whereas the latter are more complex or subjective issues, the former are directly associated with muscle biology traits of live animals and during post-mortem processing treatments.

Biotechnology is widely regarded as one of the most promising life science frontiers for the next decade. Together with informatics, biotechnology is expected to lead to revolutionary changes in our society and economy. This scientific revolution, sometimes referred to as the genomic revolution, is global and is creating new opportunities in all biological

\footnotetext{
${ }^{\dagger}$ E-mail: hocquet@clermont.inra.fr
}

sciences including medicine, human health and nutrition, agronomy and, the subject of this paper, animal science.

This paper aims to illustrate how animal scientists can take advantage of the recent developments in functional genomics to get a better understanding of the factors which determine gene expression and hence muscle physiological traits controlling beef eating quality.

\section{'Genomics': definition, history, potential benefits and limitations}

\section{Definitions and history of genomics}

In the past, molecular biologists studied one gene at a time in isolation from the larger context of other genes. This was particularly true in physiology where only a few genes characterising a specific metabolic pathway were studied together. In more recent times, high-throughput analyses of gene expression have allowed a global view of gene expression thanks to the development of techniques such as DNA arrays and proteomic approaches (Hocquette, 2005).

The first high-throughput molecular biology methods to be developed were sequencing methods. Therefore, 
sequencing of genomes from many species has been achieved or is in progress. This has facilitated a better understanding of the genome structure and the identification of polymorphisms (mainly single nucleotide polymorphisms or SNP), which allow more precise gene mapping. In beef science, this will contribute to the more rapid identification of genetic markers which will be useful for animal breeding, with the objective to improve beef quality traits as previously reviewed (Kühn et al., 2005).

Now, the application of genomics to biology is gradually evolving from the discovery of genetic determinants (structural genomics) to 'biological signatures' (functional genomics). The latter is a typical pattern of gene expression, or even a typical profile of proteins or metabolites characterising a specific physiological or pathological state. The methods to determine these biological signatures are currently reshaping biology and are referred to as transcriptomics, proteomics and metabolomics/metabonomics (Hocquette, 2005). Functional genomics therefore describes a new scientific field mid way between genetics and physiology. The current challenge for biological research is to integrate structural and functional genomics (Tuggle et al., 2006) and also to associate data from the different '-omic' sciences with phenotypic data (Hocquette, 2005). This process is facilitated by rapid developments in computational biology or bioinformatics, which has followed the rapid expansion in genomic research. Several analytical approaches, bioinformatic methods and tools have indeed been suggested to integrate data, for instance expression data at mRNA and protein levels (Cox et al., 2005) in association with metabolite profiling (Weckwerth et al., 2004) to identify real biochemical networks. More generally, bioinformatics is becoming crucial for the analysis of expression data with the ultimate objective to extract biologically meaningful information from the lists of differentially expressed genes. A variety of bioinformatic tools are available for data-mining depending on the question being asked (Hanai et al., 2006). Many experts indicated that bioinformatics and computational biology approaches will be major areas of emphasis in the next few years in both research and practical usage even for livestock (Henderson et al., 2005).

\section{Potential benefits of genomics}

The development of the new genomic high-throughput technologies is reshaping biology due to four new paradigms in science. The first one of these paradigms, can be described as a shift away from characterising a small number of key molecules (such as high differentially expressed genes or proteins), but on molecular signatures (cluster of genes, of proteins, of metabolites, etc), which are characteristic of a biological process or of a specific phenotype. This shift has been made possible with the advent of highthroughput methods of data acquisition and of bioinformatics methods to handle large amounts of data.

Another new paradigm is the change in research conception. Up to now, hypothesis-driven research has been conducted with the aim of testing new biological hypotheses which have emerged from previous studies or theoretical considerations. High-throughput genomic techniques are capable of uncovering associations between previously unknown molecules (DNA, RNA, proteins, metabolites) or previously uncharacterised DNA/protein sequences and physiological traits of interest. Genomics is thus capable of generating new biological hypotheses which can then be further studied by more focused approaches. This will impact most markedly on the characterisation of complex traits, which are governed by interactions between many genes with small effects. An example of such a complex trait is beef tenderness, which depends on connective tissue characteristics, lipid content, fibre composition and meat ageing, all complex biological phenomena in themselves.

The third new paradigm is the goal of capturing the structure-function relationships of any genome as a whole. Gene and protein studies, as well as metabolomics, will provide the link between the genome and the biological processes which give rise to the phenotype. The most important characteristics of biological organisms are their ability to change in response to changing environments. Genomics (and especially functional genomics) will thus help to understand physiology, in addition to promoting progress in genetics (Andersson and Georges, 2004).

The last important new paradigm associated with genomics is that high-throughput gene interrogation systems will help to integrate knowledge about genes associated with different physiological functions. Knowing what genes are activated following stress by the environment, infections by pathogens and increasing production levels of milk or meat will enable researchers to assess interactions between all these biological mechanisms. This will help to develop novel management and breeding strategies that simultaneously promote animal health, well-being, food quality and safety.

In medicine, genomics will be used for effective prediction of a patient's disease risk and drug reactions, and the interaction between both. Preventive medicine and medical therapy will be personalised. The development of genomic applications for personalised medicine will require associations of gene marker profiles and gene expression patterns with clinical data (Hocquette, 2005).

In agriculture and animal science, the outcomes of genomics will include improvements in food safety, in crop yield, in traceability and in quality of animal products (dairy products and meat) through increased efficiency in breeding and better knowledge of animal physiology. DNAbased techniques have been developed for the detection of bacterial contamination (beef safety), for species and animal identification (breed and individual traceability), and for genetic selection (genetic improvement of beef quality). On the other hand, RNA- and protein-based techniques may one day be used to characterise the health, physiological and nutritional status of the animals according to their breed, their genetic type, the rearing factors or the place where they are bred. These techniques may also be adapted to characterise each muscle type. For all these 
reasons, genomic techniques may contribute to quality control of beef. Protein-based techniques may be employed to monitor protein degradation during post-mortem ageing of beef, a process which controls tenderness. Therefore, genomics is likely to play a major role in sustainable agriculture due to the wide range of its potential applications (Harlizius et al., 2004). The current knowledge indicates that the major genes causing variability for similar traits in different species or breeds are rarely the same. Therefore, the study of the species of interest is needed even if research in farm animals strongly relies on the genomic knowledge in other species such as humans and model organisms (Harlizius et al., 2004).

\section{Limitations of genomics}

Many of the limitations to genomics research are of a technical nature. The technical limitations of expression array technology are still under active discussion (Shields, 2006; Sievertzon et al., 2006). Array technology is based on the principle that probes (CDNA from expressed sequence tag (EST) libraries or oligonucleotides) can be arrayed on membranes or glass slides for hybridisation with labelled targets, which originate from the biological samples of interest. The flatness of the glass support makes it possible to miniaturise the procedure. The resulting images of hybridisation are captured and analysed using software that quantifies the signal of each spot. The intensity of each spot is proportional to the amount of mRNA of the corresponding gene expressed in the studied sample.

The major technical problems that have affected expression array technology are associated with the spotted cDNA arrays which were the first forms of DNA expression arrays available and which are now almost superseded by spotted oligo arrays or manufactured oligo arrays. Problems with CDNA arrays apply generally to all species and range from the availability and inconsistent quality of molecular probes to be printed on the arrays and difficulties in array preparation (inconsistent fidelity across arrays, low specificity or low concentration of printed probes) and utilisation (Murphy, 2002; Drobyshev et al., 2003). Commercial microarray platforms, particularly those that employ in situ synthesis of oligomer probes to construct arrays are now available for the bovine and are reducing these sources of variation to very low levels. Consistent protocols for array experimentation (RNA extraction from samples, labelling, and hybridisation) and data acquisition (image capture and normalisation procedures) are emerging and microarrays are considered a reliable method for quantitating gene expression data (Canales et al., 2006).

The statistical analysis of genomic data is a challenge shared by all genomics researchers. The challenge begins with the design of large animal experiments that nevertheless contain sufficient biological replication to allow the discovery of gene expression associations with a high level of confidence. The animal genomics community has contributed to the development of microarray analysis methods by adapting the use of mixed model analysis to microarray experimentation (Reverter et al., 2003; PfisterGenskow et al., 2005). In proteomics, research by INRA scientists has also allowed improvement in statistical analyses by adapting the SAM (significance analysis of microarray) method (Meunier et al., 2005) and clustering methodologies (Meunier et al., 2007) to two-dimensional gel electrophoresis experiments.

A last challenge is to share, within the bovine community, the genomic data related to beef quality (from genetic information, transcriptomics and proteomics to phenotypes). Consequently, it is now accepted that the comparison of results from different laboratories requires standardisation procedures which have been proposed for both transcriptomic (Brazma et al., 2001) and proteomic (Taylor et al., 2003) analyses. Methods to jointly analyse microarray experimentation have been developed for a large set of bovine muscle microarray results (Reverter et al., 2005). In addition, methods have been developed for computing networks of correlated gene expression from bovine muscle gene expression data (Reverter et al., 2006).

Powerful data management tools and computational techniques are also required to store, analyse, and compare the increasing amount of genomic information in cattle. The number of expressed sequenced tags in NCBI's GenBank has now surpassed 1 million for cattle. Other specific bioinformatic databases have been developed.

Some of the existing databases and associated bioinformatic tools are devoted specifically to applications within livestock species, especially cattle (Table 1). For instance, most of the single-locus traits in livestock are listed in the OMIA (Online Mendelian Inheritance in Animals) database. Other databases have been constructed in UK (Hu et al., 2001), Australia (Hawken et al., 2004) and France (Table 1).

\section{Bovine genome sequencing and applications for breeding}

Bovine genome sequence

Sequencing of the bovine genome started in December 2003. It is under way at the Baylor College of Medicine Sequencing Centre in Houston (Texas, USA).

As set out below, the availability of the bovine genome sequence will be useful for both agricultural purposes and human health. Accordingly, the contributors to the $\$ 53$ million international effort were: the National Human Genome Research Institute, USDA (NRI and ARS), State of Texas, Genome Canada, Kleberg Foundation, Commonwealth Scientific and Industrial Research Organisation (CSIRO) Australia, New Zealand, United States Beef Council, Texas Beef Council and South Dakota Beef Council.

The animal whose DNA was sequenced is a Hereford cow, named L1 Dominette 0144. The second draft of the bovine genome sequence has been deposited into free public databases. The current assembly (Btau 3.0, August 2006) is based on a 7.1-fold coverage of the bovine 


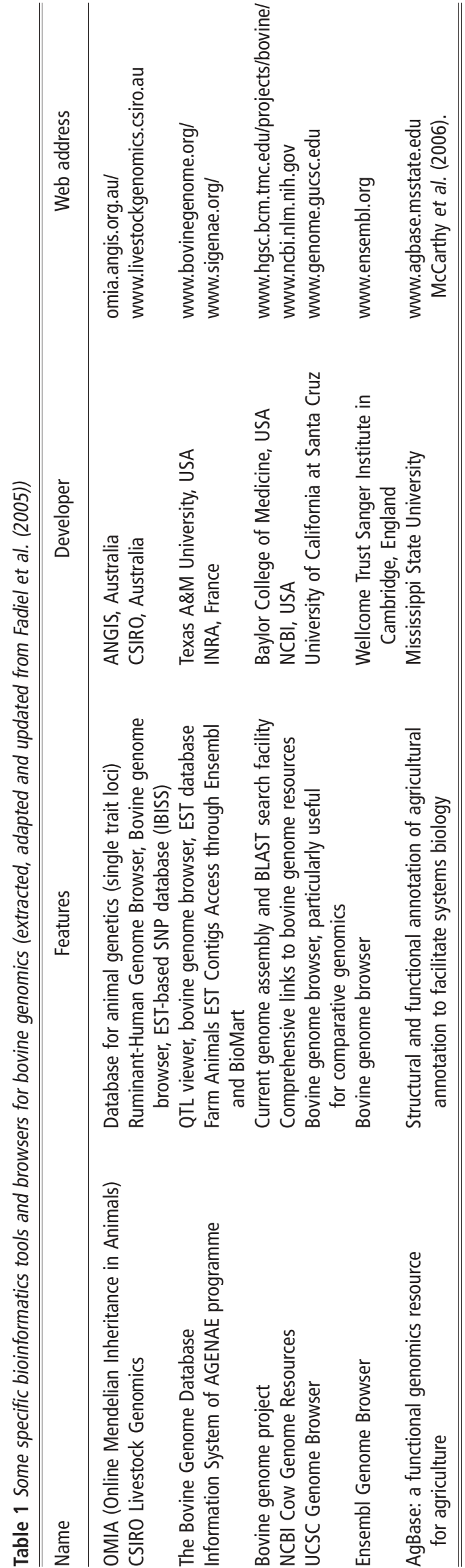

genome. The sequence data can be accessed via GenBank at NIH's National Centre for Biotechnology Information (NCBI), or via EMBL Bank at the European Molecular Biology Laboratory's Nucleotide Sequence Database and via the DNA Data Bank of Japan. A number of browsers have been developed for the bovine genome: NCBI's Map Viewer, UCSC Genome Browser at the University of California at Santa Cruz, the Ensembl Genome Browser at the Wellcome Trust Sanger Institute in Cambridge, England and the Ruminant-Human Genome Browser at CSIRO Australia (Table 1).

Sequencing at lighter coverage, to derive additional SNP, is being carried out in other breeds, such as the Holstein, Angus, Jersey, Limousin, Norwegian Red and Brahman and there are plans to also sequence the bovine $Y$ chromosome.

In a white paper (Gibbs et al., 2004), the rationale and objectives of the bovine genomic sequencing initiative were set out. Eight different biological objectives were considered. The first one is to improve human health. Understanding genetic interactions with environmental factors will indeed be a major aim of medical research in the next decades. The bovine is a valuable model to achieve this goal because a vast amount of research has been and will be conducted to study the genetic $\times$ environment interaction in this species in the case of multigenic physiological traits. The second objective is informing mammalian biology. The bovine is indeed a good model for understanding endocrinology, developing reproductive techniques and studying reproductive or metabolic diseases. For example, different cattle breeds have different capacity to deposit fat. Detailed knowledge of the molecular regulation of this trait is important for both the production of marbled beef and the understanding of obesity and diabetes in human beings. The third and fourth objectives of the bovine genome sequencing are to contribute to the annotation of the human genome sequence and to provide additional links between the sequence of humans and other species by comparative genomics. This was recently done by a high-resolution whole-genome cattle-human comparative map: 3204 ordered markers in the bovine genome over a total of 3484 are anchored in the human genome. The comparative coverage relative to the human genome is about $91 \%$. This will facilitate identification of candidate genes for economically important traits (Everts-van der Wind et al., 2005). The fifth objective is to expand our knowledge of the biological mechanisms related to health. It is suggested that alternative transcripts and post-translational modifications must play a major role in phenotypes. The phenotypic diversity of many cattle breeds throughout the world is a tremendous resource to study the molecular mechanisms which control tolerance to pathogens, altitude or heat tolerance, susceptibility to any type of illness, etc. The sixth and seventh objectives are to provide surrogate systems for human experimentations and to facilitate the ability to do experiments, especially in genetics. The last objective is to contribute to the understanding of evolutionary processes. 
To summarise, it is expected that the bovine genome sequencing, and more generally, any genomic work in cattle will have an impact not only on the livestock industries, but also on all other mammalian research, especially research into human genetics and health.

\section{Current knowledge of genetic markers in bovine}

The practical genetic issues of genomics have been described elsewhere (Renand et al., 2003; Smith et al., 2003; Kühn et al., 2005). In a few words, the objective of breeders is to exploit the variability among animals by selecting those with a superior genetic potential for the trait of interest. Many traits suitable for improvement using quantitative genetic methods are easy or inexpensive to measure on a great number of animals, but many of the important traits are not. Several of the meat quality traits, for example, are difficult to improve, such as meat tenderness and marbling, so researchers are currently looking for genes that influence genetic potential for these traits to select animals. This is a promising approach because genotyping is now increasingly easy and inexpensive to perform. One important benefit of high-throughput techniques of genomics will indeed be the identification and the practical use of polymorphisms within DNA sequences of those genes (Garnier et al., 2003; Barendse, 2005). Single nucleotide polymorphisms (SNP) are the most frequent form of DNA variation in mammals. They are abundant, normally biallelic and easy to detect by automatic techniques.

So far, polymorphisms in some genes have been reported for their association with tenderness or beef marbling (i.e. the amount of visual intramuscular fat) (Barendse, 1997; 2001 and 2003 and Barendse et al., 2004). They include the genes encoding $\mu$-calpaïn (Page et al., 2002; White et al., 2005) and lysyl oxidase and calpastatin (Barendse, 2001; Drinkwater et al., 2006) for tenderness. They also include the genes encoding leptin (Buchanan et al., 2002), DGAT1 (Thaller et al., 2003), TG (Barendse et al., 2004), RORC (Barendse, 2003), GH1 (Schlee et al., 1994), SCD, mitochondria (Mannen et al., 1998; 2003), mitochondrial transcription factor A (Jiang et al., 2005) and FABP4 (Michal et al., 2006) for marbling. Summaries of the tests have been published (e.g. Dekkers, 2004; Jeon et al., 2006) although no listing of markers is comprehensive. Other efforts are devoted to the identification of SNP in a large set of candidate genes which are associated with meat quality traits measured in 15 different European breeds. This is the EU-funded project (GeMQual, http:// www.gemqual.org/). So far, a total of about 710 SNP have been identified in 209 genes and these SNP are being genotyped in 450 bulls from the 15 breeds. The expected results are SNP that may have an effect on the carcass, muscle or meat quality traits (Hocquette et al., 2006). Table 2 contains a list of all the commercially available DNA tests for cattle, which can be obtained from web searches, although there are more tests in the literature than there are tests being offered to farmers.
Many of these associations have been confirmed in independent studies, although some have failed to be confirmed. Confirmations for the calpain and calpastatin genes have been reported by several authors (Page et al., 2004; Casas et al., 2006; Morris et al., 2006; Schenkel et al., 2006). For marbling several of the genes have been confirmed in some studies while in others some tests have failed to be confirmed (Thaller et al., 2003; Nkrumah et al., 2004; Barendse et al., 2005; Kononoff et al., 2005; Nkrumah et al., 2005; Pollak, 2005; Schenkel et al., 2005; Barendse et al., 2006; Rincker et al., 2006). Marbling is a more difficult trait to work with than tenderness, since it is a visual inspection of the carcass and hence is a measurement with a greater error, which means that it will require larger samples than normal to be detected. The failure to confirm an association usually occurs in samples where there are fewer than 1000 animals in the study. At present there are no guidelines on the composition of confirmatory studies, and different approaches are being taken in different countries. Most of the confirmations are ad hoc, however, using whatever samples are to hand. In some confirmations, the commercialiser is asked what samples they want used to evaluate the gene. Such approaches are unsatisfactory since they can lead to the type II error of accepting a null hypothesis as true when it is false, due to inadequacies in the experimental design, primarily due to sample sizes being too small. Clearly, sample sizes need to be large enough to ensure that this sort of error is minimised (Barendse, 2005).

A number of high throughput SNP genotyping platforms have recently become commercially available for the bovine. The MegAllele ${ }^{\mathrm{TM}}$ Genotyping Bovine 10K SNP Panel assays approximately 10000 SNP discovered by the Bovine Genome Sequencing Project and the CSIRO. A 32000 SNP update of this panel is about to be commercially released. Similarly, the bovine BeadChip ${ }^{\mathrm{TM}}$ genotyping system allows around 10000 bovine SNP to be assayed in parallel. A new version of the bovine iSelect BeadChip ${ }^{\mathrm{TM}}$ is under development in collaboration with the USDA-ARS, the University of Missouri-Columbia and the University of Alberta. This genotyping platform will allow the analysis of 12 samples in parallel on a single microarray with over 48000 SNP per sample. Research groups all over the world are currently applying these genotyping tools to populations of cattle extensively phenotyped for beef and dairy production and health traits. In the future, more than 1 million SNP within the Bos taurus breeds and well over 2 million with the Brahman animal included are predicted by comparing the Hereford genome assembly with traces from other breeds (Womack, 2006).

Rapid progress in discovering patterns of genetic variation that can predict animal performance can be expected from these international efforts. The increased knowledge of functional candidate genes, which will be discovered from functional genomics approaches (array data, proteomic studies) is expected to further contribute to the progress of this field. 
Hocquette, Lehnert, Barendse, Cassar-Malek and Picard

Table 2 Commercialised DNA tests for cattle QTL

\begin{tabular}{|c|c|c|c|c|}
\hline Gene $^{\dagger}$ & Trait & Year $^{\ddagger}$ & Discoverer & Commercialiser $^{\S}$ \\
\hline TG & Marbling & 2000 & CSIRO/MLA & Genetic Solutions P/L \\
\hline CAST & Meat tenderness & 2002 & CSIRO/MLA/Beef CRC & Genetic Solutions P/L \\
\hline CAPN1 & Meat tenderness & 2003 & USDA/AgResearch NZ & Open \\
\hline DGAT1 & Milk fat yield & 2003 & Univ. of Liege/Tech Uni Muench & Merial \\
\hline GH1 & Marbling & 2003 & NIAS, Japan & Prescribe Genomics CO \\
\hline LEP & Marbling/fat traits & 2003 & Univ. of Saskatchewan & Merial \\
\hline Multiple tests & Tenderness & $2003 / 4$ & & Genetic Solutions P/L \\
\hline GHR & Milk yield & 2004 & Univ. of Liege & Merial \\
\hline SCD & Fatty acid ratios & 2004 & Kobe University & Prescribe Genomics CO \\
\hline Multiple tests & Marbling & 2004 & & Genetic Solutions P/L \\
\hline Multiple tests & Multimark dairy & $2004 / 5$ & & Merial \\
\hline CAPN3 & Meat tenderness & 2006 & CSIRO/MLA/Beef CRC & Genetic Solutions P/L \\
\hline Multiple tests & Feed efficiency & 2006 & CSIRO/MLA/Beef CRC & Genetic Solutions P/L \\
\hline
\end{tabular}

${ }^{\dagger}$ Multiple tests are those based on several genes, although some tests are not based on sequences directly associated with genes, and for some tests the identity of the sequence has not been revealed.

${ }^{\ddagger}$ Year is year commercialised.

$\S$ First commercialiser, some of the tests, such as those based on CAPN1, CAST and LEP are now offered by several laboratories.

There are other discoveries of DNA markers but these are not yet available as commercialised DNA tests.

Tests for Casein and Lactoglobulin, originally milk protein variants, now DNA tests, not included in this Table, these were originally described and worked on in studies from the 1960s to mid 1984, see for example Genmark AG.

Table does not include (1) colour mutations, (2) disease mutations, (3) mutations for discrete traits such as poll/horn.

Henderson et al. (2005) predict that there are three challenges currently facing the beef industry with the use of genetic markers in genetic selection: (i) the adequate collection of DNA marker information by breed associations, (ii) quality control mechanisms for use and interpretation of DNA marker information, and (iii) increased expertise to use genetic markers discovered by the scientific communities. Furthermore, the improvement of the efficiency of markerassisted selection does require the characterisation of regulatory sequences of gene expression, the development of methods to rapidly screen genomes of multiple individuals, a better understanding of gene functions and interactions, and more emphasis on complex traits with low heritabilities.

\section{Available molecular tools for transcriptomic studies}

Tissue-specific CDNA arrays for beef quality research

Before the development of bovine cDNA microrrarrays, some groups used available human microarrays in crossspecies hybridisation studies. For instance, RNA from cattle skeletal muscle (Sudre et al., 2003 and 2005a) and oocyte (Dalbies-Tran and Mermillod, 2003) have been hybridised on human cDNA microarrays. However, because crossspecies hybridisation may generate spurious results, researchers have paid careful attention to data analysis. Therefore, interesting results were obtained despite loss of information associated with the technical constraints.

Many different research teams throughout the world have published the construction of bovine CDNA libraries from various tissues including liver and intestine (Dorroch et al., 2001; Herath et al., 2004), embryos (Potts et al., 2003; Renard et al., 2004b), endometrium (Renard et al., 2004a), uterus and ovaries (Anderson et al., 2004) and several pooled tissues (Smith et al., 2001). Several different bovine CDNA arrays were generated, specifically covering the transcriptome of, for example immune cells and tissues (Donaldson et al., 2005; Jensen et al., 2006) and other tissues of interest (Moody et al., 2003). None of these molecular tools is specifically tailored for functional genomics studies of beef quality. Therefore, arrays have been constructed from CDNA libraries derived from bovine muscles or muscle and adipose tissue (Cho et al., 2002; Lehnert et al., 2004). The number of array elements printed on these tissue-specific arrays was generally lower than that derived from multiple tissues (Suchyta et al., 2003).

Researchers from the CRC for Cattle and Beef Quality in Australia constructed a bovine microarray of 9600 elements comprising ca. 2000 EST and ca. 7300 anonymous CDNA clones from muscle and fat-derived CDNA libraries (Lehnert et al., 2004). The microarray also includes a collection of 'candidate genes' from the adipogenesis and protein turn-over literature. The main classes of genes represented on the microarray are coding for: contractile proteins (e.g. myosins, actins, etc.), extracellular matrix genes (e.g. collagens), mitochondrial enzymes (e.g. ATPases, cytochrome-c oxidase, etc.) and adipogenesisrelated molecules or binding proteins (e.g. SCD, FABP4). These gene families are associated with the main cellular components of muscle tissue: the muscle fibres themselves, connective tissue and intramuscular fat islands. The bovine fat/muscle microarray has been used in a number of experiments to track gene expression changes in muscle tissue during nutritional treatments (Byrne et al., 2005; Lehnert et al., 2006) and in breed comparisons (Wang et al., 2005a and b). The array has clear limitations for the discovery of regulatory mechanisms in muscle tissue development, as it was based on adult tissues only and therefore has very 
poor representation of probes for transcription factor genes and other regulatory factors.

One muscle specific library was prepared in France from selected various muscle types (oxidative or glycolytic) sampled from different bovine animals of various age (foetal and post-natal) and various breeds. Among the 1440 cDNAs characterised so far, 1019 from several gene families could be exploited: mitochondrial genes (133), genes encoding ribosomal proteins (100), contractile proteins, metabolic enzymes, etc. Finally, 353 cDNAs from this library and 75 CDNAs individually prepared by RT-PCR were considered as a first bovine muscle cDNA repertoire (Sudre et al., 2005b).

\section{Pooled-tissue cDNA arrays}

Tissue specific microarrays, particularly when they are based on adult tissues, have very clear limitations with respect to discovery of regulatory interactions, as they do not capture the whole transcriptome of the organism. cDNA microarrays with genome-wide representation have therefore been a goal of the scientific community since many EST collections became available and could be pooled (Table 3).

A bovine CDNA array (CattleArray 7600 from Pyxis Genomics) became available commercially in 2003. Since this array has been made with cDNAs derived from spleen and placenta, it may not be suitable to explore muscle biology and hence beef quality. A number of high-density cDNA arrays constructed for assessing genome-wide gene expression changes in cattle now include genes from muscle-specific libraries.

The NBFGC in the USA has selected 18263 genes from the pooled tissues MARC 1-4 libraries for printing on a high-density microarray (Suchyta et al., 2003). Scientists at the lowa University have followed the same strategy. They selected a set of 10608 EST from MARC 1-4 libraries which include all the known genes and unknown, putative or hypothetical genes expressed in muscle, liver or adipose tissue. The selected genes include 4484 known genes, 1170 hypothetical proteins, 497 unknown and 4364 not assigned genes. From a database of human genes expressed in muscle, liver and adipose tissue (http:// telethon.bio.unipd.it/GETProfiles/Index.html), it was calculated that the collection contains $66.37 \%, 71.02 \%$ and $67.34 \%$ of the human genes expressed in these three tissues respectively. This new library was spotted with a set of negative and positive controls. This new molecular array has been called the BoviAnalyser. It is advertised as suitable to analyse cell proliferation and differentiation in response to, for instance, disease resistance or the ability of the animals to produce marbled beef.

Scientists at the Roslin Institute's ARK-Genomics Centre in the UK have constructed high-density microarrays based mainly on its collection of immune-specific EST (McGuire and Glass, 2005) and AgResearch has been using a 10204 bovine CDNA microarray with broad genome coverage in bovine and ovine transcriptome studies (Diez-Tascón et al., 2005).

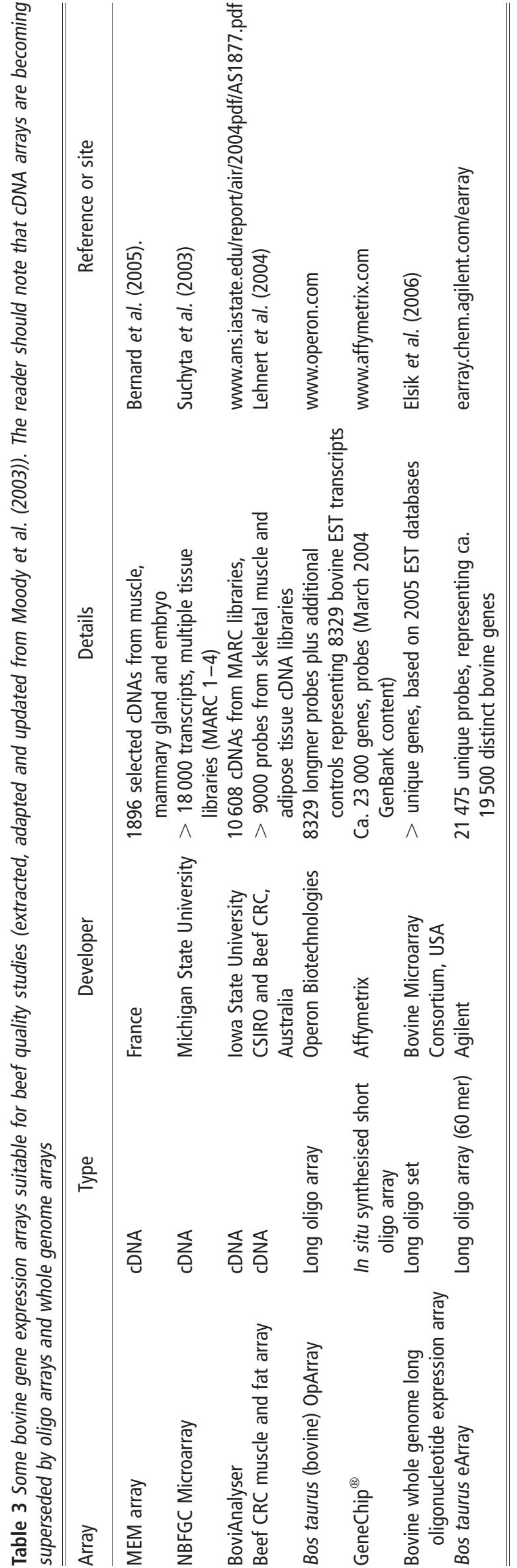


French scientists have also prepared CDNA libraries from bovine mammary gland (Le Provost et al., 1996) and embryos (Renard et al., 2004b). Their strategy is now to combine high-quality cDNA clones from their different libraries (namely from muscle, mammary gland and embryo) in the same molecular tool for gene expression profiling in bovine tissues involved in reproduction and production traits. This was reported as successful (Bernard et al., 2005). In addition, a selection of 13168 clones from the MARC 1-4 libraries (75\%) and from INRA clones (25\%) has been made to prepare an array suitable for many applications in cattle (http://sigenae.jouy.inra.fr/).

While CDNA libraries and CDNA arrays have allowed the bovine research communities to make rapid progress in transcriptomics, this technology platform is currently becoming superseded by oligo arrays and whole genome arrays.

\section{Oligo arrays}

Microarrays of synthetic oligonucleotide probes are becoming increasingly popular for transcriptomic studies, including for bovine (Table 3). The power of this approach lies largely in the opportunity to tap into the bovine genome and EST sequencing effort without the need to own libraries that contain probes of interest. Oligo arrays avoid some of the technical pitfalls of CDNA arrays, namely their lack of reliability and spot variability. The reliance on microbiological libraries of clones and their inherent contamination and handling risks has caused problems with reliability for many practitioners. The majority of the variability of microarray spots on CDNA arrays is due to the non-uniform performance of PCR reactions in probe generation. Oligo arrays are therefore of much better quality than CDNA arrays, even in heterologous systems. For instance, muscle-specific oligo arrays initially prepared for studies in mice and humans were shown to be well adapted to muscle gene expression studies in cattle (Bernard et al., 2006b). Many bovinespecific oligo arrays have also been developed for transcriptomic studies in cattle (Table 3).

Operon technologies, Inc. market a bovine oligo probe set for microarray printing. It is derived from TIGR assemblies of bovine EST available in 2004 and contains $70 \mathrm{mer}$ probes (about 8300 bovine genes with a known sequence with a hit to a known human, mouse, or cattle transcript). A bovine long oligo array project has been developed among a consortium of researchers at Texas A\&M University, University of Missouri, lowa State University, and the University of Minnesota. GenBank sequences are being analysed to remove duplicated sequences, vector sequences and other artefacts of the cloning process. This array was made available to the international community in 2006 (Elsik et al., 2006). Another oligo array project is currently developed between the University of Illinois, the University of Connecticut and INRA in France.

Affymetrix markets a high-density microarray, the GeneChip ${ }^{\circledR}$ Bovine Genome Array. It is representative of the publicly known, high-quality bovine sequences that were available in March 2004. It contains 24027 probes. It is advertised to be suitable for studies related to disease resistance, meat and dairy production as well as stress tolerance.

\section{Applications of functional genomics}

Numerous results from transcriptomic studies have been obtained so far in bovine health, normal physiology or pathology. Gene expression profiling has been used to document changes in gene expression for example following infection by pathological organisms (Meade et al., 2006), during the metabolic changes imposed by lactation in dairy cows (Loor et al., 2005), in cloned bovine embryos (Smith et al., 2005; Somers et al., 2006) and in various other models (reviewed by Henderson et al., 2005 and by Hocquette et al., 2005).

It has been forecast that the identification of differentially expressed genes may be of high importance for muscle growth and development (Reecy et al., 2006) and also for both genetic and physiological studies related to beef quality (Eggen and Hocquette, 2004). Despite this enthusiasm, some pitfalls need to be avoided. There are several reasons why the differentially expressed genes may not necessarily be the causal genes: (i) the lack of information collected on low-expressed genes (such as transcription factors and cellular regulators) is a limitation of the technology, (ii) muscle tissue is a complex mixture of cell types (myofibres, connective tissue fibroblasts, endothelial cells and adipocytes) and array studies can be simply affected by proportional changes in all these cell populations. Efforts to characterise the histological phenotype of the tissue alongside the gene expression phenotype will go some way towards addressing these issues. Notwithstanding these limitations, gene and protein expression profiling approaches have been directed at muscle of cattle (Table 4) and other livestock species, such as the pig (Lin and Hsu, 2005; Plastow et al., 2005; Cagnazzo et al., 2006). Some recent insights into bovine muscle biology that have been obtained by cattle muscle profiling are described, as follows.

\section{Comparison of gene expression between muscle types}

The first aim when looking at gene expression in various muscle types is to get a better understanding of muscle characteristics, which determine meat quality traits across muscles since the major factor of variability of tenderness is the muscle type rather than cattle breed or animal type (heifer, young bulls or cull cows) (Dransfield et al., 2003). Furthermore, some beef quality indicators, such as shear force, which is an indication of tenderness, are poorly correlated between different muscle types (Shackelford et al., 1995). Therefore, understanding differences between muscle types is of major importance in meat science.

Differences between bovine muscle types were studied by using human macroarrays (Sudre et al., 2003 and 2005a). As these arrays were initially prepared for other 
Table 4 Some examples of current initiatives in bovine genomics research applied to beef quality (extracted, adapted and updated from Henderson et al. (2005) for US projects)

\begin{tabular}{|c|c|c|}
\hline & Location & Objectives \\
\hline NC-1010 & USA & $\begin{array}{l}\text { (i) Location, structure, function and expression of genes affecting } \\
\text { health, reproduction, production and product quality in cattle, } \\
\text { (ii) interpret and apply genomics and proteomics information } \\
\text { by statistical/bioinformatics methods and utilising molecular } \\
\text { tools in cattle, and (iii) educational materials about genomics } \\
\text { research to consumers and stakeholders }\end{array}$ \\
\hline NRSP-8 & USA & $\begin{array}{l}\text { (i) Genetic and physical maps of ruminants for cross-species } \\
\text { comparisons and sequence annotations, (ii) genomic, } \\
\text { transcriptomic, proteomic and metabonomic approaches } \\
\text { toward better understanding of biological mechanisms } \\
\text { underlying economically important traits, and (iii) bioinformatics } \\
\text { tools to extract, analyse, store and disseminate information }\end{array}$ \\
\hline $\begin{array}{l}\text { ARK-Genomics Centre for } \\
\text { Comparative \& Functional } \\
\text { Genomics in Farm Animals }\end{array}$ & UK http://www.ark-genomics.org/ & $\begin{array}{l}\text { (i) Identification of traits controlling genes of agricultural and } \\
\text { biomedical importance in farm animals, (ii) integration of } \\
\text { genomics and physiological approaches to gene discovery, } \\
\text { (iii) development of a functional genomics toolkit, resources } \\
\text { and facilities for research in farm animals }\end{array}$ \\
\hline $\begin{array}{l}\text { FUGATO (Funktionelle } \\
\text { GenomAnalyse im } \\
\text { Tierischen Organismus) }\end{array}$ & Germany http://www.fugato-forschung.de/ & $\begin{array}{l}\text { (i) Host-pathogen interactions, (ii) biology and biotechnology of } \\
\text { reproduction and (iii) product quality (the QuaLIPID project } \\
\text { aims at the functional analysis of genes involved in lipid } \\
\text { metabolism) }\end{array}$ \\
\hline $\begin{array}{l}\text { AGENAE (Analyse du GENome } \\
\text { des Animaux d'Elevage) }\end{array}$ & France http://www.inra.fr/agenae/ & $\begin{array}{l}\text { Analyse of genes determining physiological functions of four } \\
\text { species (bovine, pig, poultry and trout). Specific projects } \\
\text { concern bovine muscle characteristics and beef quality: } \\
\text { MUGENE (integrated biology of beef quality including } \\
\text { genetic markers, transcriptomics and proteomics) and } \\
\text { QUALVIGENE (genetic markers of beef quality) }\end{array}$ \\
\hline $\begin{array}{l}\text { Beef CRC (Cooperative Research } \\
\text { Centre for Beef Quality) }\end{array}$ & Australia http://beefcrc.org.au & $\begin{array}{l}\text { (1) High quality beef for global consumers, (2) feed efficiency, } \\
\text { maternal productivity and responsible resource use, } \\
\text { (3) adaptation and cattle welfare, (4) female reproductive } \\
\text { performance }\end{array}$ \\
\hline
\end{tabular}

research objectives in humans, few differences were detected between muscles, however some genes of interest for muscle biology were revealed. Some of them were linked to the contractile (nebulin, actinin-associated LIM protein) or metabolic (ICDH $\beta$-subunit precursor) properties of muscles. Two interesting differentially expressed genes were LEU5 and Trip 15. LEU5 is a tumour suppressor gene associated with B-cell chronic lymphocytic leukemia. Trip 15 is a thyroid receptor interacting protein. They are probably involved in the regulation of muscle development. The differences between muscle types appeared to depend on the stage of development and the genetic types of animals (Sudre et al., 2003 and 2005a).

Similar studies should also be performed to detect the specificity of intramuscular adipose tissue (which is important for beef flavour) in comparison to other fat tissues of the carcass undesirable for beef producers.

\section{Gene expression according to the production system}

The influence of two production systems (pasture v. maizesilage indoors) on muscle gene expression was studied in France. Transcriptomic analyses using a multi-tissue bovine
cDNA repertoire were performed to compare gene expression profiling in rectus abdominis and semitendinosus muscles between both production groups. Variance analysis showed that the muscle type has an important effect on the expression level of genes. The effect of the production system was less marked. A list of the 30 most variable genes was established, of which 15 muscle genes were considered. Amongst them, the Selenoprotein W, which was found to be under-expressed on pasture, could be considered as an indicator of pasture-based system (Cassar-Malek et al., 2005a). However, whether variation of Selenoprotein $\mathrm{W}$ gene expression is linked to the feeding regime (grass $v$. maize-silage), or to the selenium status of the diet is still unclear.

\section{Gene expression throughout development}

Before the development of bovine cDNA arrays, human muscle-specific arrays were used to monitor gene expression throughout development (Sudre et al., 2003). This allowed the identification of up to 110 genes differentially expressed from 110 days post-conception to 15 months of age after birth. Among these genes, 33\% have 
unknown functions so far. Most of the differentially expressed genes are either up-regulated or down-regulated at 260 days of foetal development. This confirms the importance of the last three months of gestation in bovine muscle differentiation (Picard et al., 2002). Indeed, the number of muscle fibres is roughly fixed at two thirds of foetal development and muscle fibres differentiate before birth making cattle a relatively mature species at birth compared to other mammals. Not only did the macroarray experiment confirm this general view, but it also helped in the discovery of putative interesting genes regulated throughout development and involved in cell homeostasis (e.g. Sialyltransferase 8) or cell regulation (e.g. activin A, the thyroid receptor interacting protein 15) and in metabolic (e.g. oxoglutarate dehydrogenase) or contractile (e.g. nebulin) muscle properties (Sudre et al., 2003). Further studies are needed to explore the biological functions of the novel identified genes.

\section{Muscle gene expression profile associated with marbling}

Some sectors of the beef industry are looking for gene markers that would identify animals that have a high propensity to accumulate intramuscular fat in order to produce tasty and tender meat. In addition to research on gene expression in perirenal adipose tissue before and after fattening (Oishi et al., 2000), research by Childs et al. (2002) aimed to identify genes associated with intramuscular fat development. Differential-display polymerase chain reaction allowed the identification of a known gene (NAT1, a translational suppressor) by comparing muscle RNA from different finishing periods on high grain feeding. NAT1 was not previously suspected to play a role in fat accumulation. Putative functional genes were found to be differentially expressed (e.g. ATP citrate lyase) or, surprisingly, not differentially expressed (e.g. PPAR $\gamma$ ) between extreme animals.

Australian and Japanese scientists undertook a microarray-based comparison of the longissimus muscle (LM) from Japanese Black (JB) and Holstein (HOL) cattle over an extended intensive feeding period to identify genes that may be involved in determining the unique ability of JB cattle to deposit intramuscular (IM) fat with lower melting temperature (Wang et al., 2005a). Three consecutive biopsies from LM tissue were taken and RNA isolated from three JB (Tajima strain) and three Holstein (HOL) animals at age 11 to 20 months. The gene expression changes in these samples were analysed using a bovine fat/muscle CDNA microarray (Lehnert et al., 2004). A mixed-ANOVA model was fitted to the intensity signals. Three hundred and thirty-five (4.8\%) array elements were identified as differentially expressed genes in this breed $\times$ time comparison study. Genes preferentially expressed in JB are associated with monounsaturated fatty acid (MUFA) synthesis, fat deposition, adipogenesis development and muscle regulation, while examples of genes preferentially expressed in HOL come from functional classes involved in connective tissue and skeletal muscle development. The gene expression differences detected between the LM of the two breeds give important clues to the molecular basis for the unique features of the JB breed, such as the onset and rate of adipose tissue development, metabolic differences, and signalling pathways involved in converting carbohydrate to lipid during lipogenesis. These findings will impact on industry management strategies designed to manipulate intramuscular adipose development at different development stages to gain maximum return for beef products.

Gene and protein expression profile according to muscle growth potential

Muscle hypertrophy is of particular interest in beef meat production as it has a strong economic importance. High muscle development is associated with specific muscle characteristics in favour of meat tenderness but not of its flavour. To address the consequences of selection for increased growth rate and reduced fat content of the carcass, transcriptomic analyses of two muscles (rectus abdominis oxidative and semitendinosus glycolytic) from young bulls divergently selected on muscle growth potential were performed. The selection process in favour of muscle growth decreased oxidative muscle activity especially in rectus abdominis, which is the most oxidative muscle of both. Some genes were differentially expressed in rectus abdominis and/or semitendinosus between the two groups of bulls with high or low muscle growth potential. Many of them are involved in muscle structure (e.g. sarcosin, titin) or in cellular regulation (e.g. thyroid hormone receptor interacting protein 10, LEU5, an heat shock protein) and were more expressed in muscles from low muscle growth potential bulls compared to high muscle growth potential bulls (Sudre et al., 2005a).

Similarly, studies were conducted in double-muscled (DM) animals which are known to be characterised by a higher muscle mass and a lower fat content in the carcass and in the muscle tissue due to mutation in myostatin (a negative regulator of skeletal muscle growth which belongs to the transforming growth factor (TGF)- $\beta$ superfamily.). One challenge is nowadays to elucidate the specific mechanisms, through which myostatin signals to inhibit the growth of skeletal muscle. About 20 genes were reported to be differentially expressed between DM and normal-muscled bovine embryos at 31 to 33 days of gestation. These differentially expressed genes fall into general classes including transcription factors $(n=5)$, genes involved in protein synthesis and degradation $(n=8)$, cell proliferation $(n=3)$, or altered metabolism $(n=4)$. Three of these genes were physically mapped to bovine chromosome 5 very close to a QTL for Warner Bratzler shear force (WBS) at day 14 post mortem (an indicator of the final toughness of beef). This may be a first step to explain the link between changes in meat tenderness associated with muscle hypertrophy (Potts et al., 2003).

A recent study was conducted in order to compare the expression profile of muscle genes in the semitendinosus of double-muscled and non-double-muscled (NDM) 
260-day-old foetuses using muscle-dedicated oligochips. The differential expression of several gene categories was found. Genes involved in slow contractile properties (e.g. TNNC1, TPM3, MYH7), extracellular matrix (e.g. collagen I and III, etc.) and ribosomal proteins (e.g. RPL3, RPL23, RPS24, RPS20) were found to be under-expressed in the DM foetuses. On the other hand, genes belonging to the regulation of cell cycle (e.g p21cip1, E2F1, CTBP1), DNA metabolism and the regulation of transcription (e.g. HMGB1, mcm6, HDAC4, MEF2A, MyoD), and the protease (e.g. furin, TIMP4) were found to be over-expressed in the DM foetuses compared to normal ones. Interestingly, the expression of three differentially expressed genes (Foxc2, SIX3 and ZFHX1B) was also found in DM cows, suggesting the putative involvement of these genes in the maintenance of muscle hypertrophy (Cassar-Malek et al., 2005b). Further work is needed to understand their physiological implication in the development and modulation of muscle mass.

Similar transcriptomic studies were conducted in myostatin-knockout mice compared with wild-type mice using the Affymetrix GeneChip system. It was shown that myostatin may act upstream of Wnt pathway components, Wnt signalling being known to play a role in embryonic myogenesis. Several Wnt, including Wnt4, are capable of inducing some myogenic regulatory genes. Wnt4 is also capable of stimulating satellite cell proliferation. Based on gene expression results, a model was proposed in which Wnt4 is inhibited in the presence of myostatin, and activated in the absence of myostatin leading to stimulation of satellite cell proliferation. These results offer new insight into genes which may interact with myostatin to regulate skeletal muscle growth (Steelman et al., 2006).

To further understand how muscle hypertrophy is controlled, a proteomic analysis was developed to identify some markers of muscle mass. Two models of cattle with different origins of muscle hypertrophy: monogenic (DM Belgian Blue bulls) or polygenic (divergent lineages of Charolais bulls: with high (H) or low (L) muscle growth rate) were studied. Differential proteomic analysis of semitendinosus muscle was performed using two-dimensional gel electrophoresis (4 to $7 \mathrm{pH}$ gradient in the first dimension and $11 \%$ SDS-PAGE in the second) followed by mass spectrometric analysis of interesting spots (MALDI-TOF) as described in Bouley et al. (2004a). Proteomic analysis revealed 13 proteins corresponding to 28 protein spots significantly altered between DM and NDM muscles (Bouley et al., 2005). Among the proteins differentially expressed between the two genotypes, eight were related to contractile apparatus including myosin-binding protein $\mathrm{H}$, several myosin light chains and troponin $\mathrm{T}$ (TnT) including slow $\mathrm{TnT}$ and fast TnT. Two proteins were involved in metabolic pathways, including phosphoglucomutase and the heart fatty acid-binding protein. Finally, three proteins were significantly altered including sarcosin, sarcoplasmic reticulum $53 \mathrm{kDa}$ glycoprotein and p20. According to these data it seems that contractile properties are more modified than metabolic ones in DM muscles. Most of the modifications of protein expression are in favour of fast glycolytic properties of DM muscle. This is coherent with the data of the literature showing an orientation of muscle type towards the fast glycolytic type in case of muscle hypertrophy (reviewed by Hocquette et al. (1998)). A similar analysis was conducted on semitendinosus muscle from $\mathrm{H}$ and $\mathrm{L}$ young bulls. Interestingly, it revealed that the proteins differentially expressed in DM muscle were also differentially expressed in $\mathrm{H}$ muscle (Picard et al., 2005). Among these proteins, eleven spots of fast TnT (fTnT) were analysed more precisely. The expression levels of five of them were significantly increased in DM and $\mathrm{H}$ muscles. The levels of expression of the other six were unchanged or decreased in DM and $\mathrm{H}$ muscles. These fTnT isoforms differ in terms of the presence of the alternative splicing region corresponding to mutually exclusive exons 16 and 17 (Bouley et al., 2005, Muroya et al., 2003). All these data demonstrated that the TnT fast isoforms over-expressed in the muscle of high muscle growth potential (DM and $\mathrm{H}$ ) contained the exon 16 and the others contain the exon 17. This could constitute a good protein marker of muscle hypertrophy. This higher expression of fTnT with exon 16 in muscles of high growth potential showing an over expression of fast contractile proteins is coherent with the data from the literature: indeed, Bucher et al. (1989) showed a correlation between the expression of fTnT exon 16 and fast contractile status of muscle. Also, Jin et al. (1998) found a higher proportion of fTnT CDNA encoding the mutually exclusive fTnT exon 16 in a fast glycolytic muscle (Pectoralis).

Gene and protein expression associated with tenderness Transcriptomic and proteomic analysis of bovine muscle was also carried out in order to identify some markers of meat tenderness. For transcriptomic studies, samples of longissimus muscles from 14, 15- and 19-month-old Charolais bulls were analysed using oligo chips. Gene expression profiles were compared between high and low meat quality scores of tenderness, flavour and juiciness. Several genes were differentially expressed. Fourteen of them were highly correlated with flavour and juiciness, and one of them had a strong negative correlation with tenderness (Bernard et al., 2006b). This gene called DNAJA1 was patented because it is responsible for up to $63 \%$ of the variability in meat tenderness (Bernard et al., 2006a) although these results have to be validated using a greater number of samples. DNAJA1 encodes a protein which is a member of the large heat shock 40kDa protein family. This protein is a co-chaperone of $\mathrm{Hsc70}$ and could to play a role in protein import into mitochondria. Its involvement in beef tenderness remains unknown.

Similarly, samples of the semitendinosus muscle previously sorted according to different eating quality classes on the basis of the results of sensory analysis (Dransfield et al., 2003) were analysed by proteomic approaches. These muscles had been taken from 15-month-old bulls of three French breeds: Charolaise, Limousine and Salers. For 
the Charolaise and Limousine breeds, five protein spots were significantly altered between two classes of tenderness (Bouley et al., 2004b). Myosin binding protein $H_{\text {, }}$ Acyl-coA-binding protein, parvalbumin and a non identified protein were over-expressed in muscles of the high tenderness class. Myosin regulatory light chain 2 was underexpressed in the high tenderness class. However, these changes were not observed for the hardy Salers breed in which other proteins were altered. Because these preliminary results show that the same indicators were found in both beef breeds, this indicates that in hardy breeds such as Salers the determinism of tenderness might be different. Further analyses are in progress to complete these results on a more consequent number of samples.

\section{Conclusion}

Genomic research in cattle has to be considered in its different aspects. From the technical point of view, cattle genomics cannot be considered in isolation but will be heavily influenced by the general progress in mammalian genomics. From the scientific point of view, we must recognise that some interesting results have been obtained so far with regard to linking genomics results with aspects of beef quality. These two aspects will be dramatically reshaped with the availability of the next draft of the bovine genome sequence. The last point of view, which is of tremendous importance for economic considerations, is the prospect of practical applications of genome-based technologies to the beef industry.

From the technical point of view, genomic research of cattle is somewhat lagging behind that of model organisms despite a great deal of technical research which was recently done in cattle. Many bovine CDNA libraries have been constructed, and various bovine arrays were prepared either from cDNA libraries or from oligonucleotide probe sets designed from publicly available bovine sequences. Basic improvements in genomics using model organisms are likely to produce new tools and knowledge useful for genomics in cattle. On the other hand, the involvement of statisticians experienced in genetic statistics in cattle genomic research teams has led to some innovative developments in basic statistic methods of general interest to the microarray community. The bovine genome sequencing is forecast to be very useful for mammalian biology and health by comparing the bovine genome sequence to that of other species.

From the scientific point of view, this review has reported differentially expressed genes which were detected during bovine muscle development, between different breeds or different genotypes, between different nutritional levels or between different types of diet. A few markers of muscle hypertrophy or of beef tenderness were also identified at the mRNA or protein levels. The challenge is now to check the relevance of those key genes or proteins with the aim to use them in the near future to improve breeding or rearing strategies. The muscle tissue is however a complex tissue with different cell types (multinucleated fibres, adipocytes, etc.) in various proportions between muscles or even within the same muscle. Another challenge is to investigate which cell population is responsible for any change in gene expression.

From the economic point of view, the importance of genomics in modern agricultural practice is likely to increase. The education of producers is therefore a key issue in the adaptation of genomic research results to agricultural practice. The application of genomics and proteomics research has the potential to generate tools for beef producers that will help them to improve beef quality or to produce differentiated products. Over the longer term, these tools have the potential to change production methods in cattle breeding, husbandry and nutrition. In order to ensure efficient adoption of the outcomes of genomic research, ethical, legal, environmental, consumer and any societal concerns with the technology have to be addressed. A first success in that direction is that private partners representative of the beef industry are working together with public institutions to allow the development of the genomic research.

\section{References}

Anderson SI, Finlayson HA and Archibald AL 2004. Development of CDNA and EST resources for studying reproduction and embryo development in pigs and cattle. Accession Numbers AJ669550 to AJ697608. Available: http:// www.ncbi.nlm.nih.gov/entrez/query.fcgi?CMD = Pager\&DB = nucleotide. Accessed 28 and 29 June 2004.

Andersson L and Georges M 2004. Domestic-animal genomics: deciphering the genetics of complex traits. Natural Revue Genetique 5, 202-212.

Barendse W 1997. Assessing lipid metabolism. Patent publication W09923248, Patent US 6383751. Available: http://ep.espacenet.com/. International Publication date: 14 May 1999.

Barendse W 2001. DNA markers for meat tenderness. Patent W002064820. Patent application PCT/AU02/00122. Available: http://ep.espacenet.com/. Accessed: 22 August 2002.

Barendse W 2003. DNA markers for marbling. Patent publication W02004070055. Available: http://ep.espacenet.com/. Accessed: 19 August 2004.

Barendse W 2005. The transition from quantitative trait loci to diagnostic test in cattle and other livestock. Australian Journal of Experimental Agriculture 45, 831-836.

Barendse W, Bunch R, Thomas M, Armitage S, Baud S and Donaldson N 2004. The TG5 thyroglobulin gene test for a marbling quantitative trait loci evaluated in feedlot cattle. Australian Journal Experimental Agriculture 44, 669-674.

Barendse W, Bunch RJ and Harrison BE 2005. The leptin C73T missense mutation is not associated with marbling and fatness traits in a large gene mapping experiment in Australian cattle. Animal Genetics 36, 86-88.

Barendse W, Bunch RJ, Harrison BE and Thomas MB 2006. The growth hormone $\mathrm{GH1}: c .457 \mathrm{C}>\mathrm{G}$ mutation is associated with relative fat distribution in intra-muscular and rump fat in a large sample of Australian feedlot cattle. Animal Genetics 37, 211-214.

Bernard C, Degrelle S, Ollier S, Campion E, Cassar-Malek I, Charpigny G, Dhorne-Pollet $S$, Hue I, Hocquette JF, Le Provost $F$, Leroux C, Piumi F, Roland G, Uzbekova S, Zalachas E and Martin P 2005. A cDNA macro-array resource for gene expression profiling in ruminant tissues involved in reproduction and production (milk and beef) traits. Journal of Physiology and Pharmacology 56, (suppl. 3) 215-224.

Bernard C, Cassar-Malek I, Hocquette JF and collaborators 2006a. Genomic marker for meat tenderness. Patent 06 300943.5. 12 September 2006. 
Bernard C, Cassar-Malek I, Dubroeucq H, Renand G and Hocquette JF 2006b. Gene expression associated with beef sensory qualities. Book of abstracts of the 57th annual meeting of the European Association for Animal Production, 17-20 September 2006, Antalya, Turkey, p. 46.

Bouley J, Chambon C and Picard B 2004a. Mapping of proteins in bovine skeletal muscle using two-dimensional gel electrophoresis and mass spectrometry. Proteomics 4, 1811-1824.

Bouley J, Meunier B, Culioli J and Picard B 2004b. Analyse protéomique du muscle de bovin appliquée à la recherche de marqueurs de la tendreté de la viande. Rencontres Recherches Ruminants 11, 87-89.

Bouley J, Meunier B, Chambon C, De Smet S, Hocquette JF and Picard B 2005. Proteomic analysis of bovine skeletal muscle hypertrophy. Proteomics 5, 490-500.

Brazma A, Hingamp P, Quackenbush J, Sherlock G, Spellman P, Stoeckert C, Aach J, Ansorge W, Ball CA, Causton HC, Gaasterland T, Glenisson P, Holstege FCP, Kim IF, Markowitz V, Matese JC, Parkinson H, Robinson A, Sarkans U, Schulze-Kremer S, Stewart J, Taylor R, Vilo J and Vingron M 2001. Minimum information about a microarray experiment (MIAME)-toward standards for microarray data. Nature Genetics 29, 365-371.

Buchanan FC, Fitzsimmons CJ, van Kessel AG, Thue TD, Winkelman-Sim DC and Schmutz S 2002. Association of a missense mutation in the bovine leptin gene with carcass fat content and leptin mRNA levels. Genetics Selection Evolution 34, 105-116.

Bucher EA, De La Brousse FC and Emerson CP Jr 1989. Developmental and muscle specific regulation of avian fast skeletal troponin $\mathrm{T}$ isoform expression by mRNA splicing. Journal of Biological Chemistry 264, 12482-12491.

Byrne KA, Wang YH, Lehnert SA, Harper GS, McWilliam SM, Bruce $H L$ and Reverter A 2005. Gene expression profiling of muscle tissue in Brahman steers during nutritional restriction. Journal of Animal Science 83, 1-12.

Cagnazzo M, te Pas MF, Priem J, de Wit AA, Pool MH, Davoli R and Russo V 2006. Comparison of prenatal muscle tissue expression profiles of two pig breeds differing in muscle characteristics. Journal of Animal Science 84, 1-10.

Canales RD, Luo Y, Willey JC, Austermiller B, Barbacioru CC, Boysen C, Hunkapiller K, Jensen RV, Knight CR, Lee KY, Ma Y, Maqsodi B, Papallo A, Peters EH, Poulter K, Ruppel PL, Samaha RR, Shi L, Yang W, Zhang L and Goodsaid FM 2006. Evaluation of DNA microarray results with quantitative gene expression platforms. Nature Biotechnology 24, 1115-1122.

Casas E, White SN, Wheeler TL, Shackelford SD, Koohmaraie M, Riley DG, Chase CC, Johnson DD and Smith TPL 2006. Effects of calpastatin and mu-calpain markers in beef cattle on tenderness traits. Journal of Animal Science 84, 520-525.

Cassar-Malek I, Bernard C, Jurie C, Barnola I, Gentès G, Dozias D, Micol D and Hocquette JF 2005a. Pasture-based beef production systems may influence muscle characteristics and gene expression. In Indicators of milk and beef quality (eds JF Hocquette and S Gigli), EAAP Publication 112, pp. 385390. Wageningen Academic Publishers, Wageningen, The Netherlands.

Cassar-Malek I, Passelaigue F, Bernard C, Gautier P and Hocquette JF 2005b. Target genes of myostatin loss-of-function in bovine foetuses. Meeting of the COST action 925, 28-29 September 2005, Volos, Greece. Archiv für Tierzucht 49 (2006), Special Issue, p. 109.

Childs KD, Goad DW, Allan MF, Pomp D, Krehbiel C, Geisert RD, Morgan JB and Malayer JR 2002. Differential expression of NAT1 translational repressor during development of bovine intramuscular adipocytes. Physiological Genomics 10, 49-56.

Cho KK, Han KH, Kang SK, Lee SH and Choi YJ 2002. Applications of cDNA microarray in ruminants. The 4th Korea-Japan Joint Symposium on Rumen Metabolism and Physiology, 21-24 May 2002, Jeju, Korea, 11 pp. Available: http://rumen.snu.ac.kr/symposium/Lectures/Cho_KKpdf. Accessed: 10 December 2004.

Cox B, Kislinger T and Emili A 2005. Integrating gene and protein expression data: pattern analysis and profile mining. Methods 35, 303-314.

Dalbies-Tran R and Mermillod P 2003. Use of heterologous complementary DNA array screening to analyse bovine oocyte transcriptome and its evolution during in vitro maturation. Biology of Reproduction 68, 252-261.

Dekkers JCM 2004. Commercial application of marker- and gene-assisted selection in livestock: Strategies and lessons. Journal of Animal Science 82, E313-E328.

Diez-Tascón C, Keane OM, Wilson T, Zadissa A, Hyndman DL, Baird DB, McEwan JC and Crawford AM 2005. Microarray analysis of selection lines from outbred populations to identify genes involved with nematode parasite resistance in sheep. Physiological Genomics 21, 59-69.
Donaldson L, Vuocolo T, Gray C, Strandberg Y, Reverter A, McWilliam S, Wang $Y$, Byrne $K$ and Tellam R 2005. Construction and validation of a bovine innate immune microarray. BMC Genomics 6, 135.

Dorroch U, Goldammer T, Brunner RM, Kata SR, Kühn C, Womack JE and Schwerin M 2001. Isolation and characterization of hepatic and intestinal expressed sequence tags potentially involved in trait differentiation between cows of different metabolic type. Mammalian Genome 12, 528-537.

Dransfield E, Martin JF, Bauchart D, Abouelkaram S, Lepetit J, Culioli J, Jurie C and Picard B 2003. Meat quality and composition of three muscles from French cull cows and young bulls. Animal Science 76, 387-399.

Drinkwater RD, Li $Y$, Lenane I, Davis GP, Shorthose RP, Harrison BE, Richardson K, Ferguson D, Stevenson R, Renaud J, Loxton I, Hawken RJ, Thomas MB, Newman S, Hetzel DJS and Barendse W 2006. Detecting quantitative trait loci affecting beef tenderness on bovine chromosome 7 near calpastatin and lysyl oxidase. Australian Journal of Experimental Agriculture 46, 159-164.

Drobyshev AL, Hrabé de Anegelis M and Beckers J 2003. Artefacts and reliability of DNA microarrays expression profiling data. Current Genomics 4, 615-621.

Eggen A and Hocquette JF 2004. Genomic approaches to economic trait loci and tissue expression profiling: application to muscle biochemistry and beef quality. Meat Science 66, 1-9.

Elsik CG, Antoniou E., Fahrenkrug SC, Reecy JM, Wolfinger RD and Taylor JF 2006. A bovine whole genome long oligonucleotide expression array. 30th international conference on animal genetics, Porto Seguro, Brazil, 20-25 August 2006, Abstract C244, p. 68.

Everts-van der Wind A, Larkin DM, Green CA, Elliott JS, Olmstead CA, Chiu R, Schein JE, Marra MA, Womack JE and Lewin HA 2005. A high-resolution whole-genome cattle-human comparative map reveals details of mammalian chromosome evolution. Proceedings of the National Academy of Sciences of the United States of America 102, 18526-18531.

Fadiel A, Anidi I and Eichenbaum KD 2005. Farm animal genomics and informatics: an update. Nucleic Acids Research 33, 6308-6318.

Garnier JP, Klont R and Plastow G 2003. The potential impact of current animal research on the meat industry and consumer attitudes towards meat. Meat Science 63, 79-88.

Geay Y, Bauchart D, Hocquette JF and Culioli J 2001. Effect of nutritional factors on biochemical, structural and metabolic characteristics of muscles in ruminants; consequences on dietetic value and sensorial qualities of meat. Reproduction Nutrition Development 41, 1-26, Erratum, 377.

Gibbs R, Weinstock G, Kappes S, Loren S and Womack J 2004. White paper on bovine genomic sequencing initiative. Available: http://www.genome.gov/ Pagfes/research/Sequencing/SeqProposals/BovineSEQpdf. Accessed: 10 December 2004.

Hanai T, Hamada $\mathrm{H}$ and Okamoto M 2006. Application of bioinformatics for DNA microarray data to bioscience, bioengineering and medical fields. Journal of Biosciences and Bioengineering 101, 377-384.

Harlizius B, van Wijk R and Merks JWM 2004. Genomics for food safety and sustainable animal production. Journal of Biotechnology 113, 33-42.

Hawken RJ, Barris WC, McWilliam SM and Dalrymple BP 2004. An interactive bovine in silico SNP database (IBISS). Mammalian Genome 15, 819-827.

Henderson D, Thomas M and Da Y 2005. Conference review: bovine genomics from academia to industry. Comparative Functional Genomics 6, 174-180.

Herath CB, Shiojima S, Ishiwata H, Katsuma S, Kadowaki T, Ushizawa K, Imai K, Takahashi T, Hirasawa A, Tsujimoto G and Hashizume K 2004. Pregnancyassociated changes in genome-wide gene expression profiles in the liver of cow throughout pregnancy. Biochemical and Biophysical Research Communications 16, 666-680.

Hocquette JF 2005. Where are we in genomics? Journal of Physiology and Pharmacology 56, (suppl. 3) 37-70.

Hocquette JF and Gigli S 2005. The challenge of quality. In Indicators of milk and beef quality (ed. JF Hocquette and S Gigli), EAAP publication 112, pp. 13-22. Wageningen Academic Publishers, Wageningen, The Netherlands.

Hocquette JF, Ortigues-Marty I, Pethick D, Herpin P and Fernandez X 1998. Nutritional and hormonal regulation of energy metabolism in skeletal muscles of meat-producing animals. Livestock Production Science 56, 115-143.

Hocquette JF, Cassar-Malek I, Listrat A and Picard B 2005. Current genomics in cattle and application to beef quality. In Indicators of milk and beef quality (ed. JF Hocquette and S Gigli), EAAP publication 112, pp. 65-79. Wageningen Academic Publishers, Wageningen, The Netherlands. 
Hocquette JF, Renand G, Levéziel H, Picard B and Cassar-Malek I 2006. The potential benefits of genetics and genomics to improve beef quality - a review. Animal Science Papers and Reports 24, 173-189.

Hu J, Mungall C, Law A, Papworth R, Nelson JP, Brown A, Simpson I, Leckie S, Burt DW, Hillyard AL and Archibald AL 2001. The ARKdb: genome databases for farmed and other animals. Nucleic Acids Research 29, 106-110.

Jensen K, Talbot R, Paxton E, Waddington D and Glass EJ 2006. Development and validation of a bovine macrophage specific CDNA microarray. BMC Genomics 7, 224.

Jeon JT, Lee JH, Kim KS, Park CK and Oh SJ 2006. Application of DNA markers in animal industries. Australian Journal of Experimental Agriculture 46, 173-182.

Jiang ZH, Kunej T, Michal JJ, Gaskins CT, Reeves JJ, Busboom JR, Dovc P and Wright RW 2005. Significant associations of the mitochondrial transcription factor A promoter polymorphisms with marbling and subcutaneous fat depth in Wagyu $\times$ Limousin F-2 crosses. Biochemical and Biophysical Research Communications 334, 516-523.

Jin JP, Wang J and Ogut 0 1998. Developmentally regulated muscle typespecific alternative splicing of the $\mathrm{COOH}$-terminal variable region of fast skeletal muscle troponin $\mathrm{T}$ and an aberrant splicing pathway to encode a mutant $\mathrm{COOH}$-terminus. Biochemical and Biophysical Research Communications 242, 540-544.

Kononoff PJ, Deobald HM, Stewart EL, Laycock AD and Marquess FLS 2005. The effect of a leptin single nucleotide polymorphism on quality grade, yield grade, and carcass weight of beef cattle. Journal of Animal Science 83, 927-932.

Kühn Ch, Leveziel H, Renand G, Goldammer T, Schwerin M and Williams J 2005. Genetic markers for beef quality. In Indicators of milk and beef quality (eds JF Hocquette and S Gigli), EAAP publication 112, pp. 23-32. Wageningen Academic Publishers, Wageningen, The Netherlands.

Le Provost F, Lépingle A and Martin P 1996. A survey of the goat genome transcribed in the lactating mammary gland. Mammalian Genome 7, 657-666. Lehnert SA, Wang YH and Byrne KA 2004. Development and application of a bovine CDNA microarray for expression profiling of muscle and adipose tissue. Australian Journal Experimental Agriculture 44, 1127-1133.

Lehnert SA, Byrne KA, Reverter A, Nattrass G, Greenwood PL, Wang YH, Hudson NJ and Harper GS 2006. Gene expression profiling of bovine longissimus muscle in response and during recovery from severe chronic under nutrition. Journal of Animal Science, in press.

Lin CS and Hsu CW 2005. Differentially transcribed genes in skeletal muscle of Duroc and Taoyuan pigs. Journal of Animal Science 83, 2075-2086.

Loor JJ, Dann HM, Everts RE, Oliveira R, Green CA, Guretzky NA, RodriguezZas SL, Lewin HA and Drackley JK 2005. Temporal gene expression profiling of liver from periparturient dairy cows reveals complex adaptive mechanisms in hepatic function. Physiological Genomics 23, 217-226.

Mannen H, Kojima T, Oyama K, Mukai F, Ishida T and Tsuji S 1998. Effect of mitochondrial DNA variation on carcass traits of Japanese Black cattle. Journal of Animal Science 76, 36-41.

Mannen H, Morimoto M, Oyama K, Mukai F and Tsuji S 2003. Identification of mitochondrial DNA substitutions related to meat quality in Japanese Black cattle. Journal of Animal Science 81, 68-73.

McCarthy FM, Wang N, Magee GB, Nanduri B, Lawrence ML, Camon EB, Barrell DG, Hill DP, Dolan ME, Williams WP, Luthe DS, Bridges SM and Burgess SC 2006. AgBase: a functional genomics resource for agriculture. BMC Genomics 7, 229.

McGuire K and Glass EJ 2005. The expanding role of microarrays in the investigation of macrophage responses to pathogens. Veterinary Immunology and Immunopathology 105, 259-275.

Meade KG, Gormley E, Park SD, Fitzsimons T, Rosa GJ, Costello E, Keane J, Coussens PM and MacHugh DE 2006. Gene expression profiling of peripheral blood mononuclear cells (PBMC) from Mycobacterium bovis infected cattle after in vitro antigenic stimulation with purified protein derivative of tuberculin (PPD). Veterinary Immunology Immunopathology 113, 73-89.

Meunier B, Bouley J, Piec I, Bernard C, Picard B and Hocquette JF 2005. Data analysis methods for detection of differential protein expression in twodimensional gel electrophoresis. Analytical Biochemistry 340, 226-230.

Meunier B, Dumas E, Piec I, Hébraud M, Béchet D and Hocquette JF 2007. Assessment of hierarchical clustering methodologies for proteomic data mining. Journal of Proteome Research, in press.
Michal JJ, Zhang ZW, Gaskins CT and Jiang Z 2006. The bovine fatty acid binding protein 4 gene is significantly associated with marbling and subcutaneous fat depth in Wagyu $\times$ Limousin F2 crosses. Animal Genetics 37, 400-402.

Moody DE, Rosa AJ and Reecy JM 2003. Current status of livestock DNA microarrays. AgBiotechNet 5, 1-8.

Morris CA, Cullen NG, Hickey SM, Dobbie PM, Veenvliet BA, Manley TR, Pitchford WS, Kruk ZA, Bottema CDK and Wilson T 2006. Genotypic effects of calpain 1 and calpastatin on the tenderness of cooked M. longissimus dorsi steaks from Jersey $\times$ Limousin, Angus and Herefrod-cross cattle. Animal Genetics 37, 411-414.

Muroya S, Nakajima I and Chikuni K 2003. Amino acid sequences of multiple fast and slow troponin $\mathrm{T}$ isoforms expressed in adult bovine skeletal muscles. Journal of Animal Science 81, 1185-1192.

Murphy D 2002. Gene expression studies using microarrays: principles, problems, and prospects. Advances in Physiology Education 2, 256-270.

Nkrumah JD, Li C, Basarab JB, Guercio S, Meng Y, Murdoch B, Hansen C and Moore SS 2004. Association of a single nucleotide polymorphism in the bovine leptin gene with feed intake, feed efficiency, growth, feeding behaviour, carcass quality and body composition. Canadian Journal of Animal Science 84, 211-219.

Nkrumah JD, Li C, Yu J, Hansen C, Keisler DH and Moore SS 2005. Polymorphisms in the bovine leptin promoter associated with serum leptin concentration, growth, feed intake, feeding behavior, and measures of carcass merit. Journal of Animal Science 83, 20-28.

Oishi M, Taniguchi Y, Nishimura K, Yamada T and Sasaki Y 2000. Characterisation of gene expression in bovine adipose tissue before and alter fattening. Animal Genetics 31, 166-170.

Page BT, Casas E, Heaton MP, Cullen NG, Hyndman DL, Morris CA, Crawford AM, Wheeler TL, Koohmaraie M, Keele JW and Smith TPL 2002. Evaluation of single-nucleotide polymorphisms in CAPN1 for association with meat tenderness in cattle. Journal of Animal Science 80, 3077-3085.

Page BT, Casas E, Quaas RL, Thallman RM, Wheeler TL, Shackelford SD, Kochmaraie $M$, White SN, Bennett GL, Keele JW, Dikeman ME and Smith TPL 2004. Association of markers in the bovine CAPN1 gene with meat tenderness in large crossbred populations that sample influential industry sires. Journal of Animal Science 8, 3474-3481.

Pfister-Genskow M, Myers C, Childs LA, Lacson JC, Patterson T, Betthauser JM, Goueleke PJ, Koppang RW, Lange G, Fisher P, Watt SR, Forsberg EJ, Zheng Y, Leno GH, Schultz RM, Liu B, Chetia C, Yang X, Hoeschele I and Eilertsen KJ 2005. Identification of differentially expressed genes in individual bovine preimplantation embryos produced by nuclear transfer: Improper reprogramming of genes required for development. Biology of Reproduction $72,546-555$.

Picard B, Lefaucheur L, Berri C and Duclos MJ 2002. Muscle fibre ontogenesis in farm animal species. Reproduction Nutrition Development 42, 415-431.

Picard B, Bouley J, Cassar-Malek I, Bernard C, Renand G and Hocquette JF 2005. Proteomics applied to the analysis of bovine muscle hypertrophy. In Indicators of milk and beef quality (eds JF Hocquette and S Gigli), EAAP publication 112, pp. 379-384. Wageningen Academic Publishers, Wageningen, The Netherlands.

Plastow GS, Carrion D, Gil M, Garcia-Regueiro JA, Furnols MFI, Gispert M, Oliver MA, Velarde A, Guardia MD, Hortos M, Rius MA, Sarraga C, Diaz I, Valero A, Sosnicki A, Klont R, Dornan S, Wilkinson JM, Evans G, Sargent C, Davey G, Connolly D, Houeix B, Maltin CM, Hayes HE, Anandavijayan V, Foury A, Geverink N, Cairns M, Tilley RE, Mormede P and Blott SC 2005. Quality pork genes and meat production. Meat Science 70, 409-421, Special Issue.

Pollak EJ 2005. Application and impact of new genetic technologies on beef cattle breeding: a 'real world' perspective. Australian Journal of Experimental Agriculture 45, 739-748.

Potts JK, Echternkamp SE, Smith TPL and Reecy JM 2003. Characterization of gene expression in double-muscled and normal-muscled bovine embryos. Animal Genetics 34, 438-444.

Reecy JM, Spurlock DM and Stahl CH 2006. Gene expression profiling: insights into skeletal muscle growth and development. Journal of Animal Science 84, (suppl E) 150-154.

Renand G, Larzul C, Le Bihan-Duval E and Le Roy P 2003. L'amélioration génétique de la qualité de la viande dans les différentes espèces: situation actuelle et perspectives à court et moyen terme. INRA Productions Animales $16,159-173$. 
Renard JP, Lewin HA, Yang J, Hernandez A, Sandra O, Everts RE and Hue IE 2004a. Endometrium ESTs (bcbp). Accession Numbers CR848861 to CR 853261. Available: http://www.ncbi.nlm.nih.gov/entrez/query.fcgi?CMD=Pager\&DB=nucleotide. Accessed. 22-23 March 2005

Renard JP, Sreenan JP and Hue I 2004b. Day 14 bovine embryos (bcai) Bos taurus CDNA clone. Accession Numbers between CR942270 and CR942245 and between CR455429 and CR450858. Available: http://www.ncbi.nlm.nih.gov/entrez/query.fcgi?CMD=Pager\&DB=nucleotide. Accessed 22 March 2005.

Reverter A, Byrne KA, Bruce HL, Wang YH, Dalrymple BP and Lehnert SA 2003. Mixture model-based cluster analysis of DNA microarray gene expression data on Brahman and Brahman composite steers fed high-, medium-, and low-quality diets. Journal of Animal Science 81, 1900-1910.

Reverter A, Barris W, Moreno-Sánchez N, McWilliam S, Wang YH, Harper GS, Lehnert SA and Dalrymple BP 2005. Construction of gene interaction and regulatory networks in bovine skeletal muscle from expression data. Australian Journal of Experimental Agriculture 45, 821-829.

Reverter A, Hudson NJ, Wang Y, Tan SH, Barris W, Byrne KA, McWilliam SM, Bottema CD, Kister A, Greenwood PL, Harper GS, Lehnert SA and Dalrymple BP 2006. A gene co-expression network for bovine skeletal muscle inferred from microarray data. Physiological Genomics, in press.

Rincker CB, Pyatt NA, Berger LL and Faulkner DB 2006. Relationship among GeneSTAR marbling marker, intramuscular fat deposition, and expected progeny differences in early weaned Simmental steers. Journal of Animal Science 84, 686-693.

Schenkel FS, Miller SP, Ye X, Moore SS, Nkrumah JD, Li C, Yu J, Mandell IB, Wilton JW and Williams JL 2005. Association of single nucleotide polymorphisms in the leptin gene with carcass and meat quality traits of beef cattle. Journal of Animal Science 83, 2009-2020.

Schenkel FS, Miller JR, Jiang S, Mandell IB, Ye X, Li H and Wilton JW 2006. Association of a single nucleotide polymorphism in the calpastatin gene with carcass and meat quality traits of beef cattle. Journal of Animal Science 84, 291-299.

Schlee P, Graml R, Rottmann 0 and Pirchner F 1994. Influence of growth-hormone genotypes on breeding values of Simmental bulls. Journal of Animal Breeding and Genetics 111, 253-256.

Shackelford SD, Wheeler TL and Koohmaraie M 1995. Relationship between shear force and trained sensory panel tenderness ratings of 10 major muscles from Bos indicus and Bos taurus cattle. Journal of Animal Science 73, 3333-3340.

Shields R 2006. The emperor's new clothes revisited. Trends in Genetics 22, 463.

Sievertzon M, Nilsson P and Lundeberg J 2006. Improving reliability and performance of DNA microarrays. Expert Review of Molecular Diagnostics 6, 481-492.

Smith SL, Everts RE, Tian XC, Du F, Sung LY, Rodriguez-Zas SL, Jeong BS, Renard JP, Lewin HA and Yang X 2005. Global gene expression profiles reveal significant nuclear reprogramming by the blastocyst stage after cloning. Proceedings of the National Academy of Sciences of the United States of America 102, 17582-17587.

Smith TPL, Grosse WM, Freking BA, Roberts AJ, Stone RT, Casas E, Wray JE, White J, Cho J, Fahrenkrug JC, Bennett GL, Heaton MP, Laegreid WW, Rohrer GA, Chitko-McKown CG, Pertea G, Holt I, Karamycheva S, Liang F, Quackenbush J and Keele JW 2001. Sequence evaluation of four pooled-tissue normalized bovine cDNA libraries and construction of a gene index for cattle. Genome Research 11, 626-630.
Smith TPL, Thallman RM, Casas E, Shackelford SD, Wheeler TL and Koohmaraie M 2003. Theory and application of genome-based approaches to improve the quality and value of beef. Outlook on Agriculture 32, 253-265.

Somers J, Smith C, Donnison M, Wells DN, Henderson H, McLeay L and Pfeffer PL 2006. Gene expression profiling of individual bovine nuclear transfer blastocysts. Reproduction 131, 1073-1084.

Steelman CA, Recknor JC, Nettleton D and Reecy JM 2006. Transcriptional profiling of myostatin-knockout mice implicates Wnt signaling in postnatal skeletal muscle growth and hypertrophy. FASEB Journal 20, 580-582.

Suchyta SP, Sipkovsky S, Kruska R, Jeffers A, McNulty A, Coussens MJ, Tempelman RJ, Halgren RJ, Saama PM, Bauman DE, Boisclair YR, Burton JL, Collier RJ, DePeters EJ, Ferris TA, Lucy MC, McGuire MA, Medrano JF, Overton TR, Smith TP, Smith GW, Sonstegard TS, Spain JN, Spiers DE, Yao J and Coussens PM 2003. Development and testing of a high-density cDNA microarray resource for cattle. Physiological Genomics 15, 158-164.

Sudre K, Leroux C, Piétu G, Cassar-Malek I, Petit E, Listrat A, Auffray C, Picard B, Martin P and Hocquette JF 2003. Transcriptome analysis of two bovine muscles during ontogenesis. Journal of Biological Chemistry 133, 745-756.

Sudre K, Cassar-Malek I, Listrat A, Ueda Y, Leroux C, Jurie C, Auffray C, Renand G, Martin P and Hocquette JF 2005a. Biochemical and transcriptomic analyses of two bovine skeletal muscles in Charolais bulls divergently selected for muscle growth. Meat Science 70, 267-277.

Sudre K, Leroux C, Cassar-Malek I and Hocquette JF 2005b. A collection of bovine cDNA probes for gene expression profiling in muscle. Molecular and Cellular Probes 19, 61-70.

Taylor CF, Paton NW, Garwood KL, Kirby PD, Stead DA, Yin Z, Deutsch EW, Selway L, Walker J, Riba-Garcia I, Mohammed S, Deery MJ, Howard JA, Dunkley $T$, Aebersold R, Kell DB, Lilley KS, Roepstorff $P$, Yates JF, Brass A, Brown AJ, Cash P, Gaskell SJ, Hubbard SJ and Oliver SG 2003. A systematic approach to modeling, capturing, and disseminating proteomics experimental data. Nature Biotechnology 21, 247-254.

Thaller G, Kühn C, Winter A, Ewald A, Bellmann O, Wegner J, Zühlke H and Fries R 2003. DGAT1, a new positional and functional candidate gene for intramuscular fat deposition in cattle. Animal Genetics 34, 354-357.

Tuggle CK, Dekkers JC and Reecy JM 2006. Integration of structural and functional genomics. Animal Genetics 37, (suppl 1) 1-6.

Wang YH, Byrne KA, Reverter A, Harper GS, Taniguchi M, McWilliam SM, Mannen $\mathrm{H}$, Oyama K and Lehnert SA 2005a. Transcriptional profiling of skeletal muscle tissue from two breeds of cattle. Mammalian Genome 16, 201-221.

Wang YH, Reverter A, Mannen H, Taniguchi M, Harper GS, Oyama K., Byrne KA, Oka A., Tsuji S and Lehnert SA 2005b. Transcriptional profiling of adult muscle in Japanese Black Cattle to identify genes involved with the development of intramuscular fat. Australian Journal of Experimental Agriculture 45, 809-820.

Weckwerth W, Wenzel K and Fiehn 0 2004b. Process for the integrated extraction, identification and quantification of metabolites, proteins and RNA to reveal their co-regulation in biochemical networks. Proteomics 4, 78-83.

White SN, Casas E, Wheeler TL, Shackelford SD, Koohmaraie M, Riley DG, Chase CC Jr, Johnson DD, Keele JW and Smith TPL 2005. A new single nucleotide polymorphisms in CAPN1 extends the current tenderness marker test to include cattle of Bos indicus, Bos taurus, and crossbred descent. Journal of Animal Science 83, 2001-2008.

Womack JE 2006. The impact of sequencing the bovine genome. Australian Journal of Experimental Agriculture 46, 151-153. 